\title{
PENGARUH KONSEP DIRI TERHADAP INTENSI MEMBELI PRODUK BERMEREK PADA REMAJA DI JAKARTA
}

\author{
Lydia $^{1}$, Devi Jatmika ${ }^{2}$ \\ Program Studi Psikologi Universitas Bunda Mulia \\ 'Lydia.luphp@gmail, 20djatmika@bundamulia.ac.id
}

\begin{abstract}
Adolescence is generally focused on the physical appearance of an influence on the way they perceive themselves or are known by the term self-concept. Purchase intention each of individual is believed to be influenced by self-concept, because in it increased sense of self confidence. The purpose of this study was to assess the effect of self-concept to the intention to purchase a branded product in adolescents in Jakarta. This study uses quantitative methods with the type of causal comparative research. The study involved 158 adolescents who have been through the assessment stage of self-criticism with an age range of 15-21 years. Characteristics of the subjects in this study, namely young men and women, aged 15-21 yearsin Jakarta, and ever purchase a minimum of one kind of branded products. This research analyzed at the effect of selfconcept on the purchase intention by using simple linear regression techniques. The analysis results, showing that the self-concept have a significant influence on the purchase intention a branded product. The effect from self-concept by 5.9\%, so there are $94.1 \%$ other factors that influence could factors are environmental influences and the value of a product. Therefore, it is advisable for adolescence to be more responsible and wise before deciding to purchase a product. In addition, parents are also expected to be able to monitor and restrict children spending.
\end{abstract}

Keywords: Self-Concept, Purchase Intention, Adolescence

\begin{abstract}
ABSTRAK
Masa remaja yang umumnya berfokus pada penampilan fisik memberikan pengaruh pada cara mereka memandang dirinya sendiri atau yang dikenal dengan istilah konsep diri. Intensi membeli setiap dipercaya dipengaruhi oleh konsep diri, karena di dalamnya terdapat peningkatan rasa kepercayaan diri. Tujuan dari penelitian ini adalah untuk mengkaji pengaruh konsep diri terhadap intensi membeli produk bermerek pada remaja di Jakarta. Penelitian ini menggunakan metode kuantitatif dengan jenis penelitian kausal komparatif. Penelitian ini melibatkan 158 orang remaja yang telah melalui tahap penilaian kritik diri dengan rentang usia 15-21 tahun. Karakteristik subjek dalam penelitian ini, yaitu remaja laki-laki dan wanita, berusia 1521 tahun di Jakarta, dan pernah membeli minimal satu jenis produk bermerek. Penelitian ini menganalisa pengaruh konsep diri terhadap intensi membeli dengan menggunakan teknik regresi linier sederhana. Hasil analisis menunjukkan bahwa konsep diri memberikan pengaruh yang signifikan terhadap intensi membeli produk bermerek. Pengaruh yang diberikan konsep diri sebesar 5.9\%, sehingga masih terdapat $94.1 \%$ faktor lain yang mempengaruhi seperti faktor pengaruh lingkungan dan nilai dari suatu produk. Oleh karena itu, disarankan untuk para remaja agar lebih bertanggung jawab dan bijaksana sebelum memutuskan untuk membeli suatu produk. Selain itu, orang tua juga diharapkan agar dapat mengawasi dan membatasi pengeluaran anak.
\end{abstract}

Kata Kunci: Konsep Diri, Intensi Membeli, Remaja 


\section{PENDAHULUAN}

Masa remaja merupakan salah satu tahapan perkembangan yang akan dialami oleh setiap manusia. Pada masa ini, individu cenderung berusaha untuk dapat diterima dengan baik oleh kelompok sosialnya, sehingga berbagai hal dapat dilakukan sebagai cara menunjukan konformitas mereka (dalam Pranoto \& Mahardayani, 2010). Sarwono (2012), menyatakan usia remaja di Indonesia dimulai dari usia 11 hingga 24 tahun. Dalam masa ini, remaja memiliki prioritas perhatian pada penampilan fisik (dalam Pranoto \& Mahardayani, 2010). Citra \& Retnaningsih (2009), menyatakan bahwa cara individu memandang penampilan fisik akan mempengaruhi bagaimana cara pandang mereka terhadap diri dan juga konsep diri yang dimilikinya. Kaitan tersebut juga tampak dalam pernyataan Deaux, Dane, dan Wrightsman (dalam Sarwono \& Meinarno, 2009), bahwa konsep diri merupakan sekumpulan keyakinan dan perasaan individu mengenai dirinya, keyakinan tersebut meliputi bakat; minat; kemampuan; dan penampilan fisik, sedangkan perasaan meliputi rasa positif dan negatif; bangga atau tidak bangga; dan senang atau tidak senang dengan dirinya sendiri.

Respati, Yulianto \& Widiana (2006), menyatakan bahwa remaja yang memiliki konsep diri ke arah positif akan merasa dirinya berharga sehingga lebih percaya diri dalam menghadapi berbagai keadaan dan masalah. Sebaliknya remaja yang dengan konsep diri negatif akan mempunyai kesulitan dalam menerima diri sendiri dan sulit untuk melakukan penyesuaian diri. Konsep diri juga dipercaya dapat membantu individu dalam memandang dan mengevaluasi sebuah produk yang berkaitan dengan intensi membeli individu (Sari \& Achmat, 2013). Sejalan dengan pernyataan tersebut, Zinkham \& Hong (dalam Toth, 2014), menyatakan bahwa konsumen dapat mendefinisikan, mempertahankan, dan meningkatkan konsep diri yang dimilikinya dengan membeli dan menggunakan sebuah produk. Produk yang dipercaya dapat meningkatkan konsep diri adalah produk-produk yang memiliki harga yang mahal dan terbaru, karena banyak individu yang memahami bahwa kepercayaan diri mereka akan tumbuh ketika menggunakan produk-produk tersebut (Setiana, 2013). Sebelum sampai kepada keputusan membeli, Peter \& Olson (dalam Wisal, 2013), menyatakan bahwa individu akan melalui suatu rangkaian aktivitas yang melibatkan perhatiannya yang disebut dengan intensi membeli. Selain itu, Wisal (2013), juga menyatakan bahwa intensi membeli dapat diartikan sebagai kecenderungan individu untuk membeli sesuatu yang didalamnya terdapat rencana untuk membeli. Rencana tersebut merupakan hasil dari evaluasi individu atas suatu perilaku, harapan orang lain atas perilaku, dan potensi untuk mewujudkan perilaku tersebut, sehingga intensi membeli dapat dijadikan sebagai sebuah prediktor dari perilaku membeli (dalam Wisal, 2013).

Perilaku membeli dipercaya oleh para produsen paling berpotensi terjadi ketika individu berada tahap remaja. Hal ini disebabkan oleh penilaian para produsen yang menyatakan bahwa remaja lebih mudah terbujuk rayuan iklan, suka mengikuti teman, bersikap tidak realistis, dan cenderung boros dalam menggunakan uangnya (dalam Wahidin, 2014). Hal ini juga tergambarkan dalam salah satu fenomena, yaitu banyak remaja telah berpakaian seperti orang dewasa. Bukan hanya dalam berpakaian, remaja jaman sekarang juga sudah berdandan layaknya orang dewasa, mereka mengenakan sepatu berhak tinggi dan tas bermerek, membeli gadget terbaru, serta menggunakan kuku dan rambut palsu layaknya orang yang sudah memiliki 
penghasilan sendiri (Array, 2015).

Banyak juga dari mereka yang tidak peduli dengan keadaan ekonomi orang tua mereka agar dapat memenuhi keinginan untuk memiliki produk bermerek. Perilaku tersebut terjadi karena rasa gengsi dan demi menjaga penampilan dihadapan rekan-rekannya, sehingga mereka tidak ragu untuk menghabiskan uang sakunya atau meminta kepada orang tua untuk memenuhi hasratnya tersebut (Husain, 2014). Peneliti juga melakukan sebuah survei yang digunakan untuk mendapatkan data terkini. Peneliti melakukan survei pada bulan Desember 2015 kepada 102 orang remaja di Jakarta.

Survei ini diikuti oleh 76 remaja perempuan dan 26 remaja laki-laki yang berdomisili di Jakarta Barat (38.2\%), Jakarta Utara (24.5\%), Jakarta Pusat (13.7\%), Jakarta Timur (12.7\%), dan Jakarta Selatan (10.8\%). Responden terdiri atas 5 orang remaja yang berusia 12-15 tahun, 28 orang remaja yang berusia 16-18 tahun, dan 69 orang remaja yang berusia 19-21 tahun. Latar belakang pekerjaan responden juga beragam, yaitu pelajar $(12.7 \%)$, mahasiswa $(63.7 \%)$, karyawan (18.6\%), dan wirausaha (4.9\%). Berdasarkan hasil survei, terdapat 57 orang $(55.9 \%)$ responden yang memilih membeli produk bermerek dibandingkan tidak membeli produk bermerek. Hasil jenis produk bermerek yang paling banyak digunakan oleh responden adalah pakaian (63.7\%), gadget/smartphone (63.7\%), sepatu $(62.7 \%)$, tas (50\%), dan kosmetik $(36.3 \%)$.

Dari fenomena di atas, konsep diri yang dimiliki remaja mengarahlan bagaimana remaja menerima dan menilai dirinya sendiri dan mendorong bagaimana mereka berperilaku konsumtif. Intensi untuk memiliki barang bermerek merupakan bagian pengakuan terhadap diri mereka, tetapi dengan tuntutan karena gengsi dan mengikuti teman dapat menimbulkan permasalahan seperti perilaku boros dan tidak realistis.

Oleh karena itu, penelitian ini bertujuan untuk mengetahui pengaruh konsep diri terhadap intensi membeli produk bermerek pada remaja di Jakarta.

\section{Konsep Diri}

Konsep diri (self-concept) menurut Chaplin (dalam Respati, Yulianto, \& Widiana, 2006), merupakan evaluasi individu baik penilaian atau penaksiran mengenai dirinya sendiri. Menurut Papalia, Olds, \& Feldman (2009), konsep diri dibentuk berdasarkan interaksi individu dengan orang-orang sekitarnya, apa yang dipersepsikan orang lain mengenai diri individu yang tidak terlepas dari struktur, peran, dan status sosial yang disandang oleh seorang individu. Menurut Subadi, et al. (dalam Pardede, 2008), konsep diri bukanlah faktor yang dibawa sejak lahir, melainkan faktor yang dipelajari dan terbentuk dari pengalaman individu dalam berhubungan dengan individu lain.

Deaux, et al. (dalam Sarwono \& Meinarno, 2009), menyatakan konsep diri adalah sekumpulan keyakinan dan perasaan seseorang mengenai dirinya. Keyakinan mengenai dirinya tersebut meliputi dengan bakat, minat, kemampuan, penampilan fisik, dan lain sebagainya. Kemudian seseorang akan memiliki perasaan terhadap keyakinan mengenai dirinya tersebut, apakah orang tersebut merasa positif atau negatif, bangga atau tidak bangga, dan senang atau tidak senang dengan dirinya. Fitts (dalam Respati, Yulianto, \& Widiana, 2006) membagi konsep diri menjadi dua dimensi, yaitu:

(1) Dimensi Internal, dimensi ini dibagi lagi menjadi tiga bagian, yaitu:

(a) Identity Self, merupakan persepsi seseorang mengenai siapa dirinya, yang meliputi simbol atau label yang diberikan kepada dirinya untuk memberi 
gambaran diri dan membangun identitas dirinya.

(b) Behavioral Self, merupakan persepsi seseorang mengenai tingkah laku atau caranya bertindak.

(c) Judging Self, merupakan hasil pengamatan seseorang terhadap evaluasi dirinya, yang kemudian akan menjadi penentu kepuasan dan penerimaan individu terhadap dirinya sendiri.

(2) Dimensi Eksternal, dimensi ini dibagi lagi menjadi lima bagian, yaitu:

(a) Physical Self, merupakan persepsi dan perasaan seseorang terhadap keadaan fisik, kesehatan, keterampilan, penampilan diri, seksualitas dan gerak motorik.

(b) Moral-Ethical Self, merupakan persepsi seseorang tentang dirinya ditinjau dari standar pertimbangan nilai-nilai etis dan moral. Selain itu juga berkaitan dengan hubungan seseorang dengan Tuhannya, rasa puas seseorang pada kehidupan keagamaannya, nilainilai moral yang dianut berkenaan dengan apa yang baik dan yang jahat dan rasa puas seseorang dalam kehidupan agamanya.

(c) Personal Self, merupakan perasaan individu terhadap nilainilai pribadi terlepas dari keadaan fisik dan hubungan dengan orang lain dan sejauh mana orang tersebut merasa kuat sebagai pribadi.

(d) Family Self, merupakan perasaan dan harga diri seseorang sebagai anggota keluarga dan di tengah-tengah teman-teman dekat. Bagian ini menunjukkan seberapa jauh perasaan seseorang terhadap dirinya sebagai anggota keluarga dan terhadap peran maupun fungsi yang dijalankannya selaku anggota keluarga.

(e) Social Self, merupakan penilaian seseorang terhadap dirinya dalam berinteraksi dengan orang lain dan lingkungan lebih luas.

\section{Intensi Membeli}

Intensi membeli menurut Peter dan Olson (dalam Wisal, 2013), yaitu suatu rangkaian aktivitas yang melibatkan perhatian individu sebelum sampai pada keputusan membeli. Mowen dan Minor (2002), menyatakan bahwa intensi membeli berkaitan dengan keinginan konsumen untuk berperilaku menurut cara tertentu, seperti memiliki, membuang, dan menggunakan sebuah atau beberapa produk. Selain itu, Loudon dan Bitta (1979), menyatakan intensi membeli termasuk dalam sikap konsumen terhadap produk yang dimunculkan sebagai pertanda dari perilaku membeli (dalam Sari \& Achmat, 2013). Fishbein dan Ajzen (dalam Wisal, 2013), membagi intensi membeli menjadi tiga dimensi, yaitu:

(1) Kepercayaan berperilaku (attitude toward the behavior to aborting), merupakan kecenderungan berperilaku yang didasarkan atas keyakinan dan kepercayaan diri seseorang mengenai boleh atau tidaknya mengambil suatu tindakan, jika orang tersebut dalam kondisi atau dihadapkan pada situasi tertentu.

(2) Kepercayaan normatif (subjective norm), merupakan persepsi individu terhadap harapan dari lingkungan atau orang terdekatnya. Orang terdekat dalam hal ini disebut sebagai referen. Referen sendiri dibagi menjadi dua, yaitu: basic dan specific. Basic referen meliputi agama, peraturan, norma, budaya, dan nilai-nilai yang dianut, sedangkan specific referen meliputi orang tua, pasangan, saudara, dosen, guru, teman dekat, dan teman 
kerja. Dalam menentukan keinginan seseorang dalam mematuhi norma-norma tersebut, akan melibatkan pertimbangan individu terhadap dua komponen, yaitu: keyakinan pribadi mengenai apa yang perlu dilakukan dan keyakinan individu mengenai apa yang diharapkan oleh masyarakat atau orang-orang yang penting baginya.

(3) Kontrol kepercayaan (perceived behavioral control), merupakan persepsi seseorang tentang kemampuan dirinya dalam melakukan perilaku tertentu dan perkiraan mengenai seberapa sulit atau mudahnya.

\section{Remaja}

Remaja merupakan masa individu berkembang dari saat pertama kali tandatanda seksual sekunder muncul hingga saat individu mencapai kematangan seksualnya. Selain itu, remaja juga dapat diartikan sebagai masa individu mengalami perkembangan psikologis dan pola identifikasi dari kanak-kanak menjadi dewasa. Pada masa remaja, mereka akan berusaha agar dapat diterima dengan baik oleh kelompok sosialnya, berbagai hal dilakukan mereka sebagai cara menunjukan konformitas pada kelompoknya (dalam Pranoto \& Mahardayani, 2010). Menurut Muangman (dalam Sarwono, 2012), remaja merupakan masa peralihan dari ketergantungan sosial-ekonomi yang penuh kepada keadaan yang relatif lebih mandiri.

Sarwono (2012), menyatakan batasan usia remaja dimulai dari usia 11 hingga 24 tahun. Selain itu, Monks, Knoers \& Haditomo (2004), juga menyatakan bahwa secara global masa remaja berlangsung antara usia 12 sampai 21 tahun, di dalamnya terbagi lagi menjadi tiga masa. Masa pertama atau yang disebut masa remaja awal berlangsung antara usia 12 sampai 15 tahun, kedua masa remaja pertengahan berlangsung antara usia 15 sampai 18 tahun, dan terakhir yaitu masa remaja akhir berlangsung antara usia 18 sampai 21 tahun. Menurut Sarwono (2012) masa remaja di mulai pada usia 10 sampai 12 tahun dan berakhir pada usia18 sampai 22 tahun.

\section{METODE PENELITIAN}

Penelitian ini menggunakan metode penelitian kuantitatif. Jenis penelitian yang digunakan dalam penelitian ini adalah penelitian kausal komparatif (causal comparative research). Penelitian kausal komparatif menurut Narbuko \& Achmadi (2013), merupakan penelitian yang dilakukan untuk menyelidiki kemungkinan hubungan sebab akibat berdasarkan pengamatan terhadap akibat yang ada, mencari kembali fakta yang mungkin menjadi penyebab melalui data tertentu.

Populasi dalam penelitian ini adalah remaja Jakarta yang pernah membeli barang. Mengingat adanya keterbatasan peneliti untuk menjangkau seluruh populasi, maka peneliti hanya mengambil sebagian dari populasi yang disebut sampel untuk mewakili populasi (Gravetter \& Forzano, 2012). Penelitian ini akan menggunakan sampel sebanyak 370 orang yang terbagi dalam dua tahap, yaitu 60 orang pada tahap uji coba dan 310 orang pada tahap pelaksanaan.

Teknik sampling yang digunakan dalam penelitian ini adalah purposive sampling. Purposive sampling merupakan teknik sampling yang digunakan jika peneliti memiliki pertimbangan-pertimbangan tertentu di dalam pengambilan sampelnya (Arikunto, 2013). Peneliti menggunakan teknik sampling puposive sampling karena terdapat pertimbangan atau kriteria di dalam pengambilan sampel. Kriteria tersebut, yaitu sampel merupakan seorang remaja baik laki-laki maupun perempuan, berusia 15 sampai 21 tahun, berdomisili di Jakarta, dan pernah membeli minimal satu jenis produk bermerek. Jenis produk bermerek 
dalam penelitian ini adalah pakaian, sepatu, tas, kosmetik, gadget, jam tangan, atau parfum.

Teknik pengumpulan data dalam penelitian ini menggunakan dua buah intsrumen. Instrumen konsep diri diadaptasi dari Tennessee Self Concept Scale-II oleh Fitts \& Warren (1996) dan instrumen intensi membeli dibuat oleh peneliti dengan menggunakan teori dari Fishbein dan Ajzen (dalam Wisal, 2013).

Teknik analisa data dalam penelitian ini menggunakan perhitungan uji regresi linier sederhana. Tujuan dari perhitungan ini adalah mendapatkan besarnya pengaruh konsep diri terhadap intensi membeli produk bermerek pada remaja di Jakarta. Perhitungan regresi linier sederhana pada penelitian ini akan menggunakan program SPSS 19. Teknik regresi linier sederhana ini dipilih karena penelitian ini hanya menggunakan satu variabel terikat dan satu variabel bebas.

\section{HASIL DAN PEMBAHASAN}

Tabel 1. Norma dan Persentase Konsep Diri Subjek

\begin{tabular}{llllc}
\hline Ko & $\begin{array}{l}\text { Kategori } \\
\text { Konsep } \\
\text { Diri }\end{array}$ & $\begin{array}{l}\text { Batas } \\
\text { Skor } \\
\text { Konsep } \\
\text { Diri }\end{array}$ & $\begin{array}{c}\text { Fre- } \\
\text { kuensi }\end{array}$ & $\begin{array}{c}\text { Pers- } \\
\text { entase } \\
(\%)\end{array}$ \\
\hline 1. & Positif & $\geq 135$ & 74 & $46.84 \%$ \\
2. & Negatif & $\leq 134$ & 84 & $53.16 \%$ \\
\hline \multicolumn{5}{r}{ Total } \\
\end{tabular}

Peneliti membuat kategori gambaran konsep diri berdasarkan nilai persentil yang didapatkan. Kategori tersebut terbagi ke dalam dua kategori, yaitu kategori negatif untuk skor kurang sama dengan 134 dan kategori positif untuk skor lebih sama dengan 135 .

Peneliti juga membuat kategori gambaran konsep diri berdasarkan nilai persentil yang didapatkan. Kategori tersebut terbagi ke dalam empat kategori, yaitu kategori sangat rendah untuk skor kurang sama dengan 36, kategori rendah untuk skor 37 - 38, kategori tinggi untuk skor 39 - 41, dan kategori sangat tinggi untuk skor lebih sama dengan 42 .

Tabel 2. Norma dan Persentase Intensi Membeli Subjek

\begin{tabular}{lllll}
\hline No & $\begin{array}{l}\text { Klasifikasi } \\
\text { Intensi } \\
\text { Membeli }\end{array}$ & $\begin{array}{l}\text { Batas } \\
\text { Skor } \\
\text { Intensi } \\
\text { Membeli }\end{array}$ & $\begin{array}{l}\text { Fre- } \\
\text { kuen- } \\
\text { si }\end{array}$ & $\begin{array}{l}\text { Per- } \\
\text { sen- } \\
\text { tase }\end{array}$ \\
\hline 1. & $\begin{array}{l}\text { Sangat } \\
\text { Tinggi }\end{array}$ & $\geq 42$ & 39 & $\begin{array}{l}24.68 \\
\%\end{array}$ \\
2. & Tinggi & $39-41$ & 38 & $\begin{array}{l}24.05 \\
\%\end{array}$ \\
3. & Rendah & $37-38$ & 32 & $\begin{array}{l}20.25 \\
\%\end{array}$ \\
4. & Sangat & $\leq 36$ & 49 & $\begin{array}{l}31.02 \\
\%\end{array}$ \\
\hline Total & & & 158 & $100 \%$ \\
\hline
\end{tabular}

Pengaruh yang dihasilkan oleh konsep diri terhadap intensi membeli dilihat pada nilai tingkat signifikansi (p) dalam coefficients. Hasil analisis tingkat signifikansi dalam penelitian ini sebesar $\mathrm{p}=.002(\mathrm{p}<.01)$, maka dapat diartikan bahwa hipotesis dalam penelitian ini diterima atau terdapat pengaruh signifikan yang diberikan oleh konsep diri terhadap intensi membeli remaja di Jakarta. Selain itu, besar dari pengaruh dalam penelitian ini terlihat dari angka $\mathrm{R}$ square. Nilai R square pada penelitian ini adalah .059 atau sama dengan 5.9\%. Nilai ini didapatkan dengan cara mengkuadratkan nilai $\mathrm{R}$, pada penelitian ini nilai $R$ adalah sebesar .243. Nilai $R$ square sebesar $5.9 \%$ merupakan gambaran besaran pengaruh yang dihasilkan oleh konsep diri, sehingga masih terdapat $94.1 \%$ faktor lain yang dapat mempengaruhi intensi membeli.

Hal ini sesuai dengan pernyataan Toth (2014), yang menyatakan bahwa faktor lain yang dapat mempengaruhi perilaku membeli seseorang, seperti pengaruh lingkungan dan nilai suatu produk. Pada faktor pengaruh lingkungan, Bearden \& Etzel (dalam Toth, 2014), menyatakan bahwa penilaian dalam suatu kelompok dapat mempengaruhi seseorang ketika akan 
membuat keputusan untuk membeli sebuah produk atau merek. Tiga penilaian kelompok yang dapat memberikan pengaruh saat dalam mengambil keputusan adalah informasi, kegunaan, dan nilai yang terdapat dalam suatu produk. Faktor penilaian kelompok ini dapat menjadi pengaruh jika dikaitkan dengan partisipan yang masih berada pada tahap remaja. Robin \& Jhonson (dalam Gil, Kwon, Good, \& Jhonson, 2011), menyatakan bahwa tekanan dari teman sebaya untuk menyesuaikan diri dapat mempengaruhi remaja dalam berbagai hal, seperti berpakaian, jenis musik yang didengarkan, dan cara berperilaku.

Pada faktor nilai suatu produk, Hung, Chen, Peng, Hackley, Twisakul \& Chou (2011), melihat nilai suatu produk berdasarkan fungsi atau kualitas, pengalaman, simbolis, penampilan, dan pencapaian kebanggaan. Sementara itu, menurut Toth (2014) nilai suatu produk terbagi menjadi nilai kemewahan dan kebutuhan. Souiden, M'Saad \& Pons (dalam Toth, 2014), menyatakan bahwa produk yang memiliki nilai kemewahan adalah produk yang dapat menampilkan kekayaan, status sosial, dan meningkatkan konsep diri penggunanya. Selain itu, Bearden dan Etzel (dalam Toth, 2014), menyatakan produk dengan nilai kebutuhan adalah produk yang dapat dimiliki oleh hampir semua orang. Nilai produk inilah yang nantinya akan menjadi bahan pertimbangan individu sebelum sampai kepada keputusan membeli suatu produk.

Hasil yang didapatkan untuk gambaran konsep diri remaja pada penelitian ini adalah negatif dengan presentase sebesar 53.16\% atau sebanyak 84 orang remaja. Konsep diri negatif ini ditandai dengan beberapa ciri-ciri, seperti dalam pernyataan Montana (dalam Respati, Yulianto, \& Widiana, 2006) yaitu, mudah dipengaruhi oleh orang lain, berusaha untuk menyenangkan orang lain, menghindari keadaan sulit, dan bergantung dengan orang lain. Hal ini berkaitan dengan partisipan yang terlibat dalam penelitian yang merupakan seorang remaja, sehingga cenderung mudah terpengaruh dengan teman sebaya sebagai upaya dalam menunjukan konformitas pada kelompok (Pranoto \& Mahardayani, 2010). Hasil ini juga didukung oleh pernyataan Gil, Kwon, Good, \& Jhonson (2011), mengenai konsep diri yang berkembang dengan baik tidak akan mudah terpengaruh oleh faktor eksternal.

Selain itu, intensi membeli produk bermerek dalam penelitian ini menunjukan hasil sangat rendah dengan presentase sebesar $31.02 \%$ atau sebanyak 49 orang remaja. Intensi membeli seseorang dapat dipengaruhi oleh beberapa faktor, seperti motivasi, proses belajar, kepercayaan, dan sikap (Kotler \& Keller, 2009). Intensi membeli produk bermerek yang sangat rendah ini juga tampak dalam hasil penelitian. Hasil terbanyak yang didapatkan untuk jumlah produk bermerek yang dimiliki subjek sebanyak tiga jenis produk dengan presentase $29.11 \%$ atau sebanyak 46 orang remaja yang menjawab.

Dalam penelitian ini didapatkan juga hasil bahwa terdapat $72.15 \%$ subjek yang menyatakan alasan dalam membeli produk bermerek didasarkan oleh kualitas produk. Maka dalam penelitian ini diketahui bahwa konsep diri memberikan pengaruh yang tidak besar terhadap intensi membeli produk bermerek dan terdapat beberapa faktor lain, seperti pengaruh lingkungan dan nilai suatu produk, seperti fungsi atau kualitas, pengalaman, simbolis, penampilan, pencapaian kebanggaan, kemewahan, dan kebutuhan yang dapat mempengaruhi intensi membeli individu sebelum sampai pada keputusan membeli. 


\section{SIMPULAN DAN SARAN}

\section{Simpulan}

Simpulan yang didapatkan setelah melakukan analisis adalah gambaran konsep diri remaja dalam penelitian ini adalah negatif dengan persentase sebesar $53.16 \%$. Hal yang serupa juga terjadi dalam intensi membeli produk bermerek, dalam penelitian ini didapatkan hasil yang sangat rendah dengan presentase sebesar $31.02 \%$. dan rendah dengan presentase sebesar $20.25 \%$. Selain itu, dalam penelitian ini didapatkan hasil tingkat signifikasi $(\mathrm{p})$ sebesar $\mathrm{p}=.002(\mathrm{p}$ $<$.01), maka dapat diartikan bahwa hipotesis dalam penelitian ini diterima atau terdapat pengaruh signifikan yang diberikan oleh konsep diri terhadap intensi membeli remaja di Jakarta. Sementara itu, besarnya pengaruh yang diberikan konsep diri terhadap intensi membeli sebesar .059 atau sama dengan $5.9 \%$ dari keseluruhan pengaruh, sehingga masih terdapat $94.1 \%$ faktor lainnya, misalnya pengaruh lingkungan dan nilai suatu produk, seperti pengaruh lingkungan dan nilai suatu produk, seperti fungsi atau kualitas, pengalaman, simbolis, penampilan, pencapaian kebanggaan, kemewahan, dan kebutuhan yang ikut memberikan pengaruh dalam intensi membeli produk bermerek.

\section{Saran}

Saran untuk penelitian selanjutnya adalah meneliti faktor-faktor lain yang berpotensi mempengaruhi intensi membeli selain dari faktor yang telah dibahas dalam penelitian ini, seperti faktor lingkungan atau nilai dari suatu produk. Membuat batasan yang lebih jelas mengenai produk bermerek yang akan diteliti serta alasan subjek dalam membeli produk bermerek tersebut. Melakukan peninjauan ulang mengenai instrumen intensi membeli dalam penelitian ini, karena melihat banyaknya pernyataan yang gugur. Selain itu, peneliti selanjutnya juga dapat memfokuskan penelitian hanyak kepada satu merek dan/atau jenis produk saja.

Saran bagi para remaja adalah belajar melihat potensi yang dimiliki, sehingga dapat mengembangkan konsep diri mereka ke arah yang positif. Selain itu, para remaja juga diharapkan dapat menjadi pribadi yang mandiri dan selektif untuk menerima pengaruh dari lingkungan terutama teman sebaya. Saran bagi para orang tua adalah membantu para remaja untuk lebih selektif dalam membeli barang agar sesuai dengan kebutuhan dan mencegah munculnya perilaku konsumtif.

\section{DAFTAR PUSTAKA}

Arikunto, S. (2013). Manajemen Penelitian. Jakarta: PT Rineka Cipta.

Array, (2015). “Jangan Jadi Abege yang Penampilannya Kaya TanteTante". Diunduh dari http://news.viva.co.id/nyunyu/rea $\mathrm{d} /$ jangan-jadi-abege-yangpenampilannya-kayak-tante-tante

Citra, A. F. \& Retnaningsih. (2009). Konsep Diri Remaja Awal Putri yang Mengalami Obesitas. Jurnal Psikologi, 2(2), 166-171.

Cohen, R. J. \& Swerdlik, M. E. (2010). Psychological Testing and Assessment. New York: McGrawHill.

Crocker. L. \& Algina, J. T. (2006). Introduction to Classical and Modern Test Theory. University of Florida.

Eni, A. \& Tri, H. (2012). "Pusat-Pusat
$\begin{array}{lr}\text { Pertumbuhan di Indonesia". } \\ \text { Diunduh rari } \\ \text { http://www.ssbelajar.net/2012/12/ }\end{array}$


pusat-pusat-pertumbuhandiindonesia.html.

Gil, L. A., Kwon, K. N., Good, L. K. \& Jhonson, L. W. (2011). Impact Of Self On Attitudes Toward Luxury Brands Among Teens. Journal of Business Research, 65, 14251433.

Gravetter, F. \& Forzano, L. B. (2012). Research Methods for Behavioral Sciences. Kanada: Wadsworth Cengage Learning.

Gulö, W. (2010). Metodologi Penelitian. Jakarta: PT Gramedia.

Hung, K. P., Chen, A. H., Peng, N., Hackley, C., Tiwsakul, R. A. \& Chou, C. L. (2011). Antesedent of Luxury Brand Purchase Intention. Journal of Product \& Brand Management, 20 (6), 457-467.

Hurlock, E. B. (2003). Psikologi Perkembangan: Suatu Pendekatan Sepanjang Rentang Kehidupan edisi ke-5. Jakarta: PT Penerbit Erlangga.

Husain, N. (13 Maret 2014). "Mom, Daughter, and Branded Items!". Diunduh dari http://www.kompasiana.com/nurh ayatihusain/mom-daughter-andbrandeditems_54f82606a33311f2608b4ca c.

Kotler, P. \& Keller,K. L. (2009). Marketing Management $13^{\text {th }}$ ed. New Jersey: Pearson.

Mönks, F. J., Knoers, A. M. P., \& Haditomo, S. R. (2004). Psikologi Perkembangan: Pengantar Dalam Berbagai Bagiannya. Yogyakarta: Gadjah Mada University Press.
Mowen, J. C. \& Minor, M. (2002). Perilaku Konsumen edisi ke-5. Jakarta: PT Penerbit Erlangga

Narbuko, C. \& Achmadi, A. (2013). Metodologi Penelitian. Jakarta: PT Bumi Aksara.

Nazir, M. (2009). Metode Penelitian. Bogor: Ghalia Indonesia.

Nisfiannoor, M. (2009). Pendekatan Statistika Modern: Untuk Ilmu Sosial. Jakarta: Salemba Humanika

Pardede, Y. O. K. (2008). Konsep Diri Anak Jalanan Usia Remaja. Jurnal Psikologi, 1 (2), 146-151.

Papalia, D. E., Olds, S. W. \& Feldman, R. D. (2009). Experience Human Development $11^{\text {st }} \mathrm{ed}$. New York: McGraw-Hill.

Putra, B. S. (2012). Hubungan Antara Konsep Diri dengan Prestasi Belajar Siswa SMA Santo Lukas Penginjili I.

Pranoto, W., \& Mahardayani, I. H. (2010). Perilaku Konsumen Remaja Menggunakan Produk Fashion Bermerek Ditinjau dari Kepercayaan Diri. Jurnal Psikologi Universitas Muria Kudus, 1 (1), 9-14.

Respati, W. S., Yulianto, A., \& Widiana, N. (2006). Perbedaan Konsep Diri Antara Remaja Akhir yang Mempersepsi Pola Asuh Orang Tua Authoritarian, Permissive, dan Authoritative. Jurnal Psikologi, 4 (2), 199-138.

Sari, V. A. K., \& Achmat, Z. (2013). Konsep Diri Independen dengan Intensi Membeli Sepeda Fixie. 
Jurnal Ilmiah Psikologi Terapan, 1 (1), 85-96.

Setiana, R. (20 April 2013). “Waspadai Gaya Hidup Konsumtif dan Shopaholic!". Diunduh dari http://mjeducation.com/waspadaigaya-hidup-konsumtif-danshopaholic/.

Santrock, J. W. (2009). Adolescence. New York: McGraw-Hill.

Sarwono, S. W. (2012). Psikologi Remaja. Jakarta: PT Raja Grafindo Persada.

Sarwono, S. W. \& Meinarno, E. A. (2009). Psikologi Sosial. Jakarta: Salemba Humanika.

Seniati, L., Yulianto, A., \& Setiadi, B. N. (2006). Psikologi Eksperimen. Jakarta: Indeks.

Siregar, S. (2013). Metode Penelitian Kuantitatif. Jakarta: Kencana Prenada Media Grup.

Sugiyono. (2015). Statistika Untuk Penelitian. Bandung: Alfabeta.

Toth, M. (2014). The Role of SelfConcept in Consumer Behavior.

Wahidin, D. (17 Mei 2014). "Pola Konsumtif Remaja di Mal Sebagai Bentuk Refleksi Gaya Hidup". Diunduh dari http://www.siperubahan.com/read /626/Pola-Konsumtif-Remaja-diMal-Sebagai-Bentuk-RefleksiGaya-Hidup.

Wahyudi. (2013). Tinjauan Tentang Perilaku Konsumtif Remaja Pengunjung Mall Samarinda Central Plaza. Ejournal Sosiologi, 1 (4), 26-36.

Wildyana., \& Suyasa, P. T. Y. S. (2006). Persepsi terhadap Kemasan dan Intensi Membeli. Jurnal Ilmiah
Psikologi Industri dan Organisasi, 8 (2), 110-124.

Wisal, J. S. F. (2013). Hubungan Antara Motivasi dengan Intensi Membeli pada Konsumen Tas Branded. Jurnal Ilmiah Mahasiswa Universitas Surabaya, 2 (2), 1-27. 